\title{
Implementasi Quiz Interaktif dengan Software Mentimeter dalam Meningkatkan Hasil Belajar
}

\author{
Vera Septi Andrini ${ }^{1 *}$, Hendrik Pratama ${ }^{2}$ \\ 1,2 Pendidikan Matematika, STKIP PGRI Nganjuk, Nganjuk, Indonesia
}

\section{ART ICLE INFO}

Article history:

Received May 09, 2021

Revised May 15, 2021

Accepted July 09, 2021

Available online August 25, 2021

Kata Kunci:

Quiz Interaktif, Mentimeter,

Hasil Belajar

Keywords:

Learning Outcomes, Quiz Interactive, Mentimeter

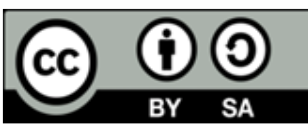

This is an open access article under the CC BY-SA license.

Copyright () 2021 by Author. Published by Universitas Pendidikan Ganesha.

\begin{abstract}
A B S T R A K
Hasil belajar mahasiswa rendah. Hal ini disebabkan oleh penerapan model pembelajaran yang kurang inovatif di masa pandemi Covid-19 saat ini. Tujuan penelitian ini adalah menganalisis penggunaan kuis interaktif menggunakan aplikasi mentimeter dalam meningkatkan hasil belajar. Jenis penelitian yang digunakan adalah komparatif. Jenis desain penelitian yang diguakan adalah one group pretest-posttest design. Sampel dalam penelitian ini berjumlah 25 mahasiswa semester III yang menempuh mata kuliah Mekanika. Teknik pengumpulan data yang digunakan adalah tes, angket, dan dokumentasi. Analisis data penelitian menggunakan uji statistik yang digunakan yaitu Uji T Paired. Hasil penelitian menunjukkan ada perbedaan hasil belajar mahasiswa antara sebelum dan sesudah perlakuan. Rata-rata hasil belajar jika berdasarkan nilai postest sebesar 78,00 lebih besar daripada nilai pretest sebesar 68,00 . Pengunaan aplikasi mentimeter sebagai kuiz interaktif membuat mahasiswa lebih termotivasi dalam mengikuti proses pembelajaran. Antarmahasiswa menunjukkan adanya kompetisi yang positif setiap diadakan kuis. Implikasi penelitian ini diharapkan dapat meningkatkan proses pembelajaran menjadi lebih menyenangkan layaknya bermain menggunakan smartphone.
\end{abstract}

\section{A B S T RACT}

The problem studied in this study is the low student learning outcomes. This is due to the application of learning models that are less innovative during the current Covid-19 pandemic. The purpose of this study was to analyze the effect of using an interactive quiz using the Mentimeter application in improving learning outcomes. The type of research used is comparative. The sample in this study amounted to 25 third semester students who took the Mechanics course. Data collection techniques used are tests, questionnaires, and documentation. Analysis of research data using statistical tests used is the Paired $T$ Test. The results showed that there were differences in student learning outcomes between before and after treatment. The average learning outcome if based on the posttest score of 78.00 is greater than the pretest score of 68.00. The use of the Mentimeter application as an interactive quiz makes students more motivated in participating in the learning process. Between students shows a positive competition every time a quiz is held. The implications of this research are expected to improve the learning process to be more fun like playing using a smartphone.

\section{PENDAHULUAN}

Kemajuan teknologi berperan penting dalam dunia pendidikan. Guru dituntut memiliki keterampilan yang lebih dalam mengelola kegiatan pembelajaran, mengikuti perkembangan teknologi dan informasi, dan menciptakan inovasi dalam mendukung proses belajar mengajar (Van Laar et al., 2017; Sumantri, 2019). Teknologi sangat dibutuhkan untuk membantu guru dalam menyampaikan sebuah materi. Salah satunya dengan merancang suatu media pembelajaran dengan memanfaatkan kemajuan teknologi (Tindowen et al., 2017). Banyak penelitian sebelumnya menyatakan bahwa media pembelajaran memberikan pengaruh signifikan terhadap pembelajaran dan memberikan dampak positif terhadap hasil belajar. Ilmu pengetahuan dan teknologi sangat diperlukan untuk mendukung pembelajaran karena dapat menjembatani antara teknologi dan pembelajaran di dalam kelas. Salah satu pemanfaatan teknologi sebagai media pembelajaran adalah menggunakan perangkat android. Selama ini, android banyak dimanfaatkan sebagai alat komunikasi. Selain itu, perangkat android juga berpotensi dikembangkan 
sebagai media pembelajaran interaktif yang bermanfaat bagi peserta didik. Komponen yang sangat penting dalam menunjang keberhasilan proses pembelajaran adalah media pembelajaran. Hasil belajar merupakan tolok ukur keberhasilan proses pembelajaran (Gopal et al., 2021; Sa et al., 2021). Hasil belajar merupakan tindakan yang mencerminkan kompetensi peserta didik yang berhasil menggunakan konten, informasi, ide-ide, dan alat-alat dalam pembelajaran (Kristiyani \& Budiningsih, 2019; Mahajan \& Singh, 2017; Maimuna, 2020). Oleh karena itu, hasil belajar sebagai kompetensi dan keterampilan yang wajib dimiliki dan diperoleh siswa setelah masa pembelajaran (Elde Mølstad \& Karseth, 2016).

Namun kenyataannya, selama pembelajaran jarak jauh yang memanfaatkan media online atau dalam jaringan (daring), banyak kendala yang dialami oleh dosen. Salah satu yang terlihat adalah menurunnya hasil belajar mahasiswa (Fikri et al., 2021; (Rigianti, 2020). Hasil jawaban dari setiap tugas mahasiswa cenderung copas (copy paste) dari teman atau berdasarkan sumber lain seperti internet. Banyak yang hanya menyalin jawaban tanpa mempelajari isi dan maksud dari tulisan tersebut. Hal ini berdampak pada saat uian. Saat ujian berlangsung, banyak siswa yang tidak bisa mengerjakan soal yang telah diberikan oleh dosen. Rata-rata hasil belajar sebesar 57 dengan kategori cukup. Bahkan ada hampir 40\% mahasiswa harus melakukan remidi setiap diadakan ujian atau kuiz. Jika permasalahan itu dibiarkan akan memberikan dampak buruk pada kualitas pendidikan. Maka dari itu, perlunya sebuah inovasi dari pendidik untuk mulai memanfaatkan platform digital untuk mendukung proses pembelajaran di kelas.

Penggunaan platform digital lebih bisa mendorong dan memotivasi siswa untuk melakukan pekerjaan yang lebih baik serta dapat mengembangkan keterampilannya (Nuriyawan \& Wibawa, 2020; Tohara, 2021). Salah satu solusi yang dapat dilakukan dengan menerapkan metode pembelajaran berbasis kuiz interaktif dengan memanfaatkan aplikasi online mentimeter sebagai upaya untuk meningkatkan hasil belajar mahasiswa. Mentimenter merupakan aplikasi online yang memungkinkan penggunanya untuk menampilkan berbagai diagram hasil interaksi sosial sekelompok orang. Misalnya, polling atau pendapat yang disampaikan secara terbuka dan singkat. Mentimenter sangat potensial untuk menjaga interaksi kelas walaupun diselenggarakan dengan tidak bertemu langsung (Istiandaru \& Prabowo, 2020; Green et al., 2020). Mentimeter menjadi alat bantu yang mendukung proses pembelajaran yang memungkinkan pendidik dan peserta didik berinteraksi secara langsung (Makris, 2021). Aplikasi ini gratis namun bisa diupgrade untuk mendapatkan fitur tambahan. Mentimeter dilengkapi dengan menu presentation dengan aneka model seperti multiple choice, word cloud, open ended, dan lainnya (Mahmashony, 2018). Aplikasi ini juga memungkinkan untuk upload gambar, grafik, membuat quote, menampilkan report hasil jawaban siswa jika dibuat dalam bentuk soal, memberikan informasi jawaban, dan masih banyak lagi. Manfaat mentimeter yaitu mampu memberikan efek ketertarikan siswa selama proses pembelajaran sebagai media pendukung pengumpulan data, media mengemukakan pendapat, dan media pembuatan soal interaktif (Khasanah \& Sari, 2021).

Temuan penelitian sebelumnya menyatakan kuis interaktif praktis dan efektif dari segi waktu dan ekonomi ketika digunakan (Virgiawan et al., 2018). Penggunaan soal interaktif yang inovatif dan variatif secara mandiri, sehingga akan terbentuk kegiatan evaluasi yang variatif dan menyenangkan (Purnanto \& Mahardika, 2017). Keuntungan lain yang diperoleh yaitu guru dapat menyusun soal berbasis computer dan soal berbasis kertas dalam satu waktu (Seraj \& Wong, 2014; Wang et al., 2021). Perbedaan penelitian sebelumnya yaitu menerapkan instrumen tanpa menggunakan aplikasi. Sedangkan penelitian ini penggunaan kuis interaktif menggunakan aplikasi mentimeter dalam meningkatkan hasil belajar mahasiswa Program Studi Pendidikan IPA STKIP PGRI Nganjuk. Penelitian ini bertujuan untuk mengetahui perbedaan pengaruh penggunaan aplikasi Mentimeter dalam meningkatkan hasil belajar mahasiswa.

\section{METODE}

Jenis penelitian komparatif digunakan dalam penelitian ini. Penelitian komparatif merupakan penelitian yang membandingkan keadaan satu variabel atau lebih pada sampel dalam waktu yang berbeda. Populasi penelitian ini menggunakan seluruh mahasiswa Program Studi Pendidikan IPA STKIP PGRI Nganjuk tahun akademik 2020/2021. Sampel dalam penelitian ini adalah mahasiswa semester III yang menempuh mata kuliah Mekanika dengan jumlah 25 mahasiswa. Penelitian ini mengkaji perbedaan hasil belajar mahasiswa jika ditinjau dari penerapan strategi pembelajaran berbasis kuiz. Jenis desain penelitian yang digunakan adalah one group pretest-posttest design, yaitu kegiatan penelitian yang memberikan tes awal (pretest) sebelum diberikan perlakuan dan setelah diberikan perlakuan barulah memberikan tes akhir (posttest). Sebelum melakukan treatment, setiap mahasiswa diberikan pretest. Langkah selanjutnya pemberian treatment dengan memberikan model pembelajaran menggunakan quiz interaktif berbantuan software mentimeter. Sebagai langkah akhir, mahasiswa diberikan postest dengan tujuan untuk mengetahui aspek hasil belajar mahasiswa. Teknik pengumpulan data menggunakan angket, 
tes, dan dokumentasi. Penilaian hasil belajar mahasiswa diukur menggunakan metode tes. Indikator tes pada ranah hasil belajar (ranah pengetahuan) menggunakan C1 (mengingat), C2 (memahami), C3 (mengaplikasikan), dan C4 (menganalisis). Jenis tes yang digunakan adalah esai yang berjumlah 10 soal. Kisi-kisi postest yang digunakan seperti disajikan dalam Tabel 1.

Tabel 1. Kisi-kisi Postest Hasil Belajar

\begin{tabular}{|c|c|c|c|c|c|}
\hline \multirow[t]{2}{*}{$\begin{array}{l}\text { Kompetensi } \\
\text { Dasar }\end{array}$} & \multirow[t]{2}{*}{ Indikator } & \multicolumn{4}{|c|}{$\begin{array}{c}\text { Tipe Kompetensi Ranah } \\
\text { Pengetahuan }\end{array}$} \\
\hline & & C1 & $\mathrm{C} 2$ & C3 & C4 \\
\hline $\begin{array}{l}\text { Menganalisis } \\
\text { konsep } \\
\text { momentums dan } \\
\text { impuls, serta } \\
\text { hukum kekekalan } \\
\text { momentum dalam } \\
\text { kehidupan sehari- } \\
\text { hari }\end{array}$ & 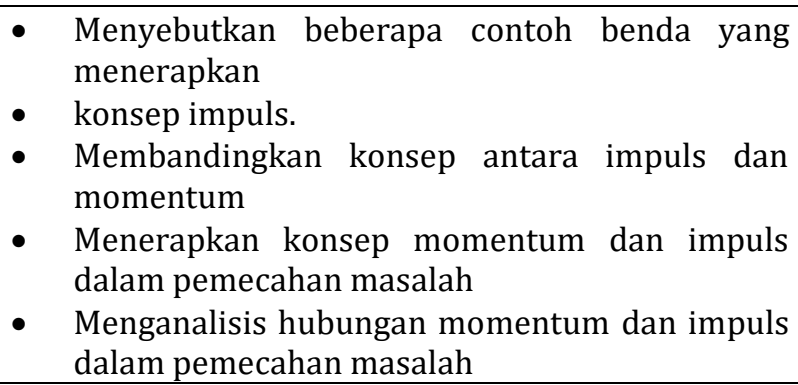 & $\mathrm{V}$ & $\mathrm{V}$ & $\mathrm{v}$ & $\mathrm{v}$ \\
\hline
\end{tabular}

Analisis data penelitian menggunakan uji statistik yang digunakan yaitu Uji T Paired atau Paired T Test. Uji ini dimaksudkan untuk mengetahui perbedaan rata-rata dua sampel yang saling berpasangan. Syarat Uji T Paired adalah perbedaan dua kelompok data berdistribusi normal. Maka harus dilakukan terlebih dahulu dengan uji normalitas pada perbedaan kedua kelompok tersebut menggunakan uji normalitas Kolmogorov Smirnov.

\section{HASIL DAN PEMBAHASAN}

Berdasarkan hasil analisis data implementasi quiz interaktif dengan software mentimeter dalam meningkatkan hasil belajar. Hasilnya ditunjukkan pada Tabel 2.

Tabel 2. Paired Samples Statistik

\begin{tabular}{|c|c|c|c|c|c|}
\hline & & Mean & $\mathbf{N}$ & Std. Deviation & Std. Error Mean \\
\hline \multirow[t]{2}{*}{ Pair 1} & Pretest & 68,0000 & 25 & 7,93200 & 1,58640 \\
\hline & Postest & 78,0000 & 25 & 8,30662 & 1,66132 \\
\hline
\end{tabular}

Berdasarkan Tabel 2, rata-rata nilai postest sebesar 78,00 lebih besar daripada nilai pretest sebesar 68,00. Hal ini menunjukkan bahwa penggunaan kuiz interaktif memberikan pengaruh terhadap hasil belajar. Besarnya pengaruh ini dapat dilihat berdasarkan data Paired Samples Correlations dengan nilai korelasi antara 2 variabel tersebut: Hasil 0,951 artinya hubungan kuat dan positif. Berdasarkan Tabel 3 , Nilai probabilitas/p value uji T Paired: Hasil $=0,000$. Artinya, ada perbedaan antara sebelum dan sesudah perlakuan. Nilai $p$ value $>0,05$ (95\% kepercayaan). Mean: $-1,000$. Bernilai negatif artinya terjadi kecenderungan kenaikan hasil belajar sesudah perlakuan. Rata-rata kenaikan sebesar 1,00. Hasil uji Ngain menunjukkan nilai rata-rata sebesar 0,34 (dalam kategori sedang).

Tabel 2. Paired Samples Test

\begin{tabular}{|c|c|c|c|c|c|c|c|}
\hline \multirow{2}{*}{ Mean } & \multirow{2}{*}{$\begin{array}{c}\text { Std. } \\
\text { Deviation }\end{array}$} & \multirow{2}{*}{$\begin{array}{l}\text { Std. } \\
\text { Error } \\
\text { Mean }\end{array}$} & \multicolumn{2}{|c|}{$\begin{array}{l}\text { 95\% Confidence Interval of } \\
\text { the Difference }\end{array}$} & \multirow{2}{*}{$t$} & \multirow{2}{*}{ df } & \multirow{2}{*}{$\begin{array}{l}\text { Sig. (2- } \\
\text { tailed) }\end{array}$} \\
\hline & & & Lower & Upper & & & \\
\hline$-1.00 \mathrm{E}+01$ & 2.5658 & 0.51316 & -11.0591 & -8.94089 & 19.487 & 24 & 0 \\
\hline
\end{tabular}

Gambar 1 menunjukkan bahwa sebanyak 25 mahasiswa telah melakukan prestest dan postest. Hasil sebelum dan setelah perlakuan menunjukkan perbedaan yang signifikan. Rata-rata capaian pembelajaran mahasiswa yang semula 68,47 dalam kategori cukup meningkat menjadi 78,58 dalam kategori baik. Capaian hasil belajar ini tentunya merupakan kontribusi dari penerapan kuis interaktif menggunakan aplikasi mentimeter. Mahasiswa tidak takut lagi setiap akan menghadapi ujian. Tapi justru 
sangat antusias dan tertantang untuk mengikuti ujian. Pada akhir pembelajaran, dilaksanakan evaluasi dan pembahasan oleh dosen. Hasilnya ditemukan beberapa miskonsepsi dari jawaban yg diberikan mahasiswa. Tabel 4 merupakan salah satu contoh miskonsepsi mahasiswa dalam memahami kosep teori.

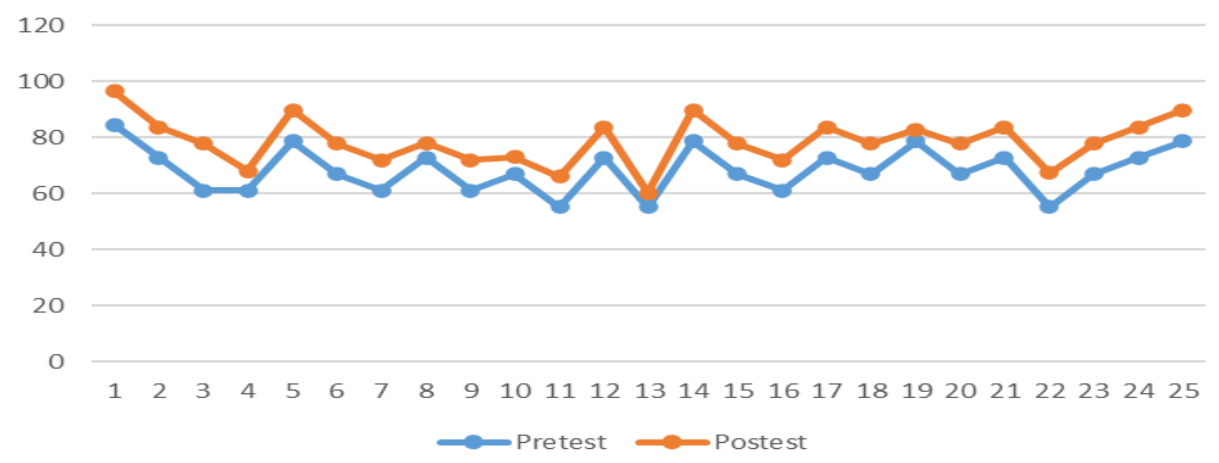

Gambar 1. Hasil Nilai Pretest dan Postest

Tabel 4. Pembahasan Hasil Uji Soal

\begin{tabular}{ll}
\hline No & \multicolumn{2}{c}{ Pertanyaan } \\
\hline 1 & Sebuah truk bermassa \\
& $2000 \mathrm{~kg}$ dan sebuah \\
& mobil $1000 \mathrm{~kg}$ bergerak \\
& dengan kecepatan yang \\
& sama. Dalam \\
& perjalanannya, tiba-tiba \\
& truk berhenti dan mobil \\
& itu tetap bergerak. \\
& Bagaimanakah \\
& momentum keduanya \\
& sesaat setelah truk \\
& berhenti ?
\end{tabular}

dan besar kecepatan kedua benda tidak berpengaruh. Sebanyak $19.0 \%$ berpikir bahwa momentum suatu benda hanya dipengaruhi oleh massanya saja atau kecepatannya saja.

Momentum sebuah truk bermassa 2000 $\mathrm{kg}$ dan sebuah mobil bermassa $1000 \mathrm{~kg}$ memiliki momentum yang sama besarnya sesaat setelah truk itu berhenti karena siswa beranggapan bahwa truk dan mobil memiliki kecepatan awal yang sama. Selain itu, beberapa mahasiswa juga ada yang menjawab bahwa momentum truk lebih besar dibandingkan momentum mobil karena mereka beranggapan bahwa massa truk lebih besar dibandingkan massa mobil

2 Momentum termasuk besaran ...

\begin{abstract}
Mahasiswa
sebanyak menganggap bahwa $15.87 \%$ termasuk besaran scalar sebab dipengaruhi oleh besarnya massa dan atau besarnya kecepatan karena mereka sering memahami bahwa penulisan persamaan momentum adalah $p=m \cdot v$
\end{abstract}

\section{Penjelasan}

Sebuah truk dan mobil memiliki kecepatan yang sama. Massa truk lebih besar disbanding massa mobil. Dalam perjalanan, tiba-tiba truk berhenti dan mobil tetap bergerak, maka momentum keduanya setelah truk berhenti adalah momentum truk lebih kecil dibandingkan momementum mobil sebab saat truk berhenti, truk tidak memiliki kecepatan sedangkan mobil masih memiliki kecepatan karena bergerak.

Momentum merupakan besaran vector sebab momentum memiliki arah yang sama dengan arah kecepatan.

Berdasarkan Gambar 2, respon mahasiswa terhadap penggunaan kuiz interaktif dengan memanfaatkan aplikasi mentimeter diukur berdasarkan 5 indikator yaitu rasa senang, minat, antusiasme, keaktifan, dan ketertarikan. Kemudian, indikator ini dibuat dalam bentuk angket. Hasilnya menunjukkan bahwa pada indikator rasa senang mahasiswa selama proses pembelajaran meningkat dari $68 \%$ menjadi $80 \%$, indikator minat meningkat dari $60 \%$ menjadi $79 \%$, indikator antusiasme meningkat dari $72 \%$ menjadi $87 \%$, indikator keaktifan meningkat dari $66 \%$ menjadi $84 \%$, dan indikator ketertarikan meningkat dari 66\% menjadi 85\%. Peningkatan hasil belajar ini tentunya menunjukkan bahwa penerapan kuis interaktif ini cukup efektif. Walupun demikian, masih ada beberapa mahasiswa yang mendapatkan nilai kurang maksimal. Hat tersebut disebabkan oleh kekurangsempurnaan atau error sistem pada 
perangkat smartphone yang digunakan mahasiswa. Hadirnya quiz interaktif dalam mendukung proses belajar mengajar sangat tepat guna meningkatkan hasil dan motivasinya (Hill, 2020); Purba, 2020). Mentimeter dalam penelitian ini digunakan sebagai aplikasi membuat quiz interaktif. Kegiatan dimulai dari instruktur membuat presentation dalam bentuk soal, kemudian siswa login dengan cara memasukkan kode pin. Pastisipasi peserta didik ini bisa melalui smartphone atau laptop. Setelah login, mahasiswa tinggal mengerjakan soal secara real time. Pada tahap awal, soal kuis dikerjakan secara berkelompok yang terdiri dari 4 sampai 5 mahasiswa. Tiap kelompok berkompetisi untuk memperoleh hasil yang terbaik. Kelompok yang mampu menjawab dengan benar setiap pertanyaan dan juga mempu menjawab lebih cepat daripada kelompok lain akan dinyatakan sebagai pemenang. Dari kegiatan ini, rasa kebersamaan dan kekompakan akan terbentuk. Tiap mahasiswa juga menjadi lebih percaya diri dan termotivasi untuk berkontribusi dalam kelompoknya. Kegiatan selanjutnya, barulah dilakukan kuis mandiri. Pelaksanaan kuis dan tata caranya sama dengan kuis secara berkelompok. Perbedaannya, pada kuis mandiri, mahasiswa bekerja tanpa bantuan tim. Hal ini bermaksud untuk melatih kemandirian belajar dan juga untuk mengetahui kemampuan dari setiap mahasiswa. Pada akhir pembelajaran, dosen juga memberikan reward. Pemberian reward ini dimaksudkan untuk membuat mahasiswa semakin antusias memperhatikan dosen serta dalam mengerjakan tugas yang diberikan. Selain itu mahasiswa juga mampu bersikap baik selama proses pembelajaran (Febianti, 2018; Sujiantari, 2016).

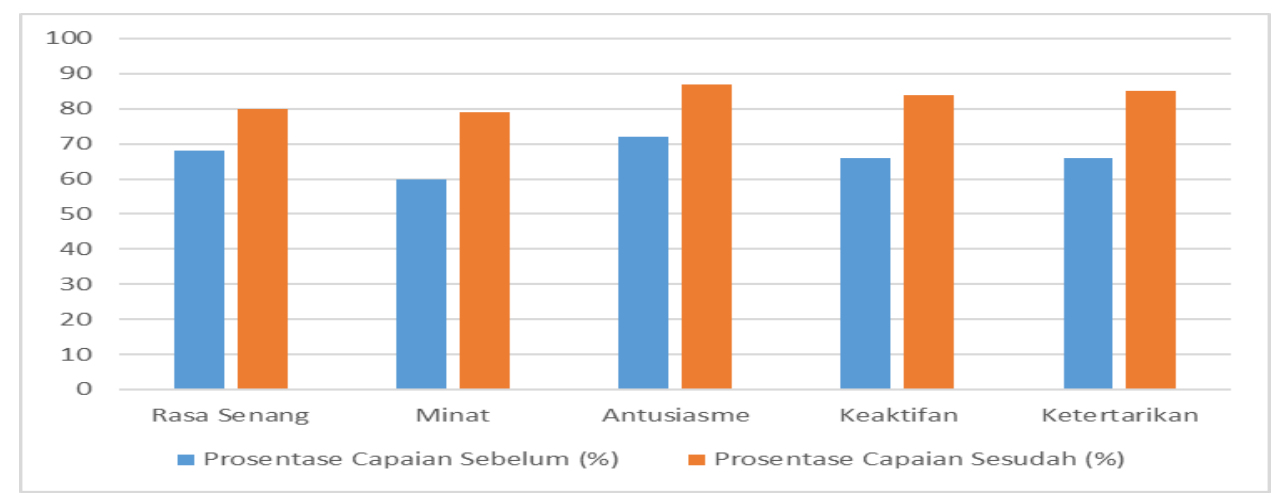

Gambar 2. Persepsi Mahasiswa sebelum dan Sesudah Pengunaan Kuiz

Mentimeter interaksi antara presenter (dalam hal ini guru) dan audiens (peserta didik) dapat disajikan dalam presentasi dengan fitur memberikan umpan balik langsung (feedback) melalui smartphone, tablet, PC atau laptop (Gokbulut, 2020); Khasanah \& Sari, 2021). Sementara informasi pribadi apa pun dari siswa tidak tercermin di layar sistem, sehingga siswa yang memiliki kemampuan pasif dan rasa malu pada teman sebaya di kelas dapat berpartisipasi aktif dan termotivasi karena turut berkesempatan aktif di kelas. Namun, mahasiswa dengan skor terbaik dan tercepat dalam menjawab benar untuk setiap soal dapat langsung diketahui dan ditampilkan. Hal ini berfungsi untuk memberikan suasana kompetisi dan semangat bagi mahasiswa yang lain. Hadirnya teknologi menjadi faktor penting bagi pendidik untuk merancang model pembelajaran yang interaktif. Tidak bisa dipungkiri bahwa hampir setiap mahasiswa telah memiliki fasilitas smartphone. Hal ini memungkinkan dosen untuk memberikan model pembelajaran berbasis online tanpa kendala. Aplikasi mentimeter yang digunakan dalam kegiatan proses pembelajaran sangat mendukung, khususnya dalam membuat kuis interaktif. Aplikasi mentimeter merupakan media yang praktis digunakan dalam presentasi, mudah digunakan, dan sangat familiar dengan pengguna (Andriani et al., 2019); Ibnu Muttaqin, 2021). Selain itu, manfaat teknologi juga sangat besar bagi mahasiswa khususnya sebagai calon guru. Mahasiswa harus mampu menguasai, memanfaatkan, dan memilih teknologi yang mendukung proses belajar mengajar. Oleh karena itu, pengenalan dan penerapan aplikasi maupun software sangat diperlukan sejak dini untuk melatih keterampilan mahasiswa (Kayandra \& Agustin, 2020; Nasution, 2018).

Saling berkompetisi untuk mendapatkan skor tertinggi dan tercepat untuk menjadi pemenang (Vallely \& Gibson, 2018). Kuis interaktif ini merupakan sebuah aplikasi yang berisi materi pelajaran dalam bentuk soal yang memungkinkan peserta didik untuk meningkatkan pengetahuannya mengenai materi pelajaran (Mualimah et al., 2019). Perlu diketahui, karena kuis interaktif ini berbasis online, maka jaringan dan perangkat perlu disiapkan sebaik mungkin agar tidak terjadi kendala saat penerapannya (Centauri, 2019; Hutauruk, 2020). Data di atas menunjukkan bahwa mahasiswa sangat antusias terhadap model pembelajaran yang diberikan. Untuk mendukung proses pembelajaran, diharapkan hasil ini mampu memberikan kontribusi yang nyata. Misalnya bagi mahasiswa, perangkat lunak berbasis kuiz inetraktif ini 
menawarkan hal baru dan kesempatan untuk berpartisipasi secara langsung, meningkatkan keaktifan, dan motivasi dalam belajar. Mahasiswa menjadi lebih percaya diri dan tanpa rasa takut untuk menyampaikan pendapat. Melalui model pembelajaran inovatif dengan memanfaatkan software maka suasana kelas daring menjadi lebih kondusif, meningkatkan kebersamaan, dan menciptakan kompetisi bersaing yang positif (Pratama et al., 2021); Raimanu, 2020).

Keterbatasan penelitian ini adalah dalam mode daring, pendidik kesulitan mendeteksi proses mahasiswa saat menjawab kuiz. Dikhawatirkan jika saat menjawab kuiz, mahasiswa berada dalam tempat yang sama. Rekomendasi dari penelitian ini, yaitu dengan adanya perkembangan teknologi dan komunikasi di era digitalisasi perlu didukung oleh semua pelaku pendidikan. Pemanfaatan mentimeter dalam proses pembelajaran ini merupakan salah satu penerapan media pendukung ditengah pesatnya perkembangan yang terjadi. Aplikasi ini mudah digunakan, gratis, dan memiliki fitur yang cukup menarik. Dosen maupun mahasiswa hanya perlu menyiapkan komputer, laptop, atau smartphone untuk mendukung penggunaan aplikasi ini. Jangka panjang, dosen sebaiknya juga tetap mengikuti perkembangan teknologi yang ada, baik itu dari online, playstore, maupun yang lainnya, sehingga memiliki banyak variasi pilihan dalam mendukung proses pembelajaran.

\section{SIMPULAN}

Hasil penelitian menunjukkan bahwa ada perbedaan hasil belajar mahasiswa antara sebelum dan sesudah perlakuan. Hal ini didukung data yang menunjukkan rata-rata hasil belajar postest lebih baik dari nilai postest. Aplikasi mentimeter yang digunakan merupakan jenis media pembelajaran yang dapat dimanfaatkan dalam mendukung aktivitas belajar mengajar dalam mode daring. Respon mahasiswa selama proses pembelajaran juga menunjukkan hasil yang positif.

\section{DAFTAR PUSTAKA}

Andriani, A., Dewi, I., \& Sagala, P. N. (2019). Development of Blended Learning Media using the Mentimeter Application to Improve Mathematics Creative Thinking Skills. Journal of Physics: Conference Series, 1188(1), 12112. https://doi.org/10.1088/1742-6596/1188/1/012112.

Centauri, B. (2019). Efektivitas Kahoot! sebagai Media Pembelajaran Kuis Interaktif Di SDN-7 Bukit Tunggal. Jurnal: Seminar Nasional Pendidikan Mipa Dan Teknologi (SNPMT II), 1(1), 124-133. https://journal.ikippgriptk.ac.id/index.php/snpmt2/article/view/1360.

Diah Rusmala Dewi. (2019). Pengembangan Kurikulum di Indonesia Menghadapi Tuntutan Kompetensi Abad 21. As-Salam: Jurnal Studi Hukum Islam \& Pendidikan, 8(1), 1-22. https://doi.org/10.51226/assalam.v8i1.123.

Elde Mølstad, C., \& Karseth, B. (2016). National Curricula in Norway and Finland: The Role of Learning Outcomes. European Educational Research Journal, 15(3), 329-344. https: //doi.org/10.1177/1474904116639311.

Febianti, Y. N. (2018). Peningkatan Motivasi Belajar dengan Pemberian Reward and Punishment yang Positif. Edunomic Jurnal Pendidikan Ekonomi, 6(2), 93. https://doi.org/10.33603/ejpe.v6i2.1445.

Gokbulut, B. (2020). The Effect of Mentimeter and Kahoot Applications on University Students' ELearning. World Journal on Educational Technology: Current Issues, 12(2), 107-116. https: //doi.org/10.18844/wjet.v12i2.4814.

Gopal, R., Singh, V., \& Aggarwal, A. (2021). Impact of Online Classes on the Satisfaction and Performance of Students during the Pandemic Period of COVID 19. Education and Information Technologies, 0123456789, 1-25. https://doi.org/10.1007/s10639-021-10523-1.

Green, J. K., Burrow, M. S., \& Carvalho, L. (2020). Designing for Transition: Supporting Teachers and Students Cope with Emergency Remote Education. Postdigital Science and Education, 2(3), 906922. https://doi.org/10.1007/s42438-020-00185-6.

Hill, L. (2020). Mentimeter: A Tool for Actively Engaging Large Lecture Cohorts. Academy of Management Learning \& Education, 19(2), 256-258. https://doi.org/10.5465/amle.2019.0129.

Hutauruk, A., \& Sidabutar, R. (2020). Kendala Pembelajaran Daring selama Masa Pandemi di Kalangan Mahasiswa Pendidikan Matematika: Kajian Kualiatatif Deskriptif. SEPREN: Journal of Mathematics Education and Applied, 02(01), 45-51. https://doi.org/10.36655/sepren.v2i1.364.

Istiandaru, A., \& Prabowo, A. (2020). Pelatihan Pembelajaran Inovatif Berbasis Mentimeter. Seminar Nasional Hasil Pengabdian Kepada Masyarakat, 251-256.

Jiemsak, N., \& Jiemsak, R. (2020). The Effectiveness of the Quizizz Interactive Quiz Media as an Online SelfAssessment of Undergraduate Students to Improve Students' Learning Outcomes. 2020 5th 
International STEM Education Conference, ISTEM-Ed 2020, 1567(2), 51-54. https://doi.org/10.1109/iSTEM-Ed50324.2020.9332675.

Kayandra, Y., \& Agustin, F. (2020). Perancangan Aplikasi Media Pembelajaran Interaktif Menggunakan Metode Linear Congruent Method (LCM) Pengenalan Danau di Indonesia Berbasis Android. Jurnal Mahasiswa Fakultas Teknik Dan Ilmu Komputer, 1(1), 1231-1240. http://e-journal.potensiutama.ac.id/ojs/index.php/FTIK/article/view/974.

Khasanah, F. N., \& Sari, R. (2021). Pelatihan Mentimeter sebagai Media Interaksi dalam Pembelajaran Daring pada SMAN 14 Bekasi. Journal of Computer Science Contributions (JuCosCo), 1(1), 42-52.

Kristiyani, E., \& Budiningsih, I. (2019). Pengaruh Strategi Pembelajaran dan Minat Belajar terhadap Hasil Belajar Matematika. Akademika, 8(01), 81-100. https://doi.org/10.34005/akademika.v8i01.341.

Mahajan, M., \& Singh, M. K. S. (2017). Importance and Benefits of Learning Outcomes. IOSR Journal of Humanities and Social Science, 22(03), 65-67. https://doi.org/10.9790/0837-2203056567.

Mahmashony, S. (2018). Optimalisasi Pengajaran Aqidah dengan Google Classroom dan Interactive Mentimeter pada Prodi Farmasi FMIPA UII. Journal of Information and Computer Technology Education, 2(1), 1-7. https://doi.org/10.21070/jicte.v2i1.600.

Maimuna, L. (2020). Mutu Hasil Belajar Aljabar Linear melalui Pembelajaran Daring di Palcomtech Palembang. Wacana Akademika: Majalah Ilmiah Kependidikan, 4(2), 130. https://doi.org/10.30738/wa.v4i2.8491.

Mualimah, A., Praherdhiono, H., \& Adi, E. (2019). Pengembangan Kuis Interaktif Nahwu sebagai Media Pembelajaran Drill and Practice Pada Pembelajaran Nahwu Di Pondok Pesantren Salafiyah Putri Al-Ishlahiyah Malang. Jurnal Kajian Teknologi Pendidikan, 2(3), 203-212. https://doi.org/10.17977/um038v2i32019p203.

Muhammad Fikri, Muhammad Zaki Ananda, N. F. (2021). Kendala dalam Pembelajaran Jarak Jauh di Masa Pandemi Covid-19: Sebuah Kajian Kritis. Jurnal Education and Development Institut Pendidikan Tapanuli Selatan, 9(1), 145-148. https://doi.org/10.37081/ed.v9i1.2290.

Muttaqin, M. E. I. (2021). Komparasi Penggunaan Digital Tools pada Perkuliahan Daring di Masa Pandemi. In JURUS JITU (p. https://files.osf.io/v1/resources/f5t2c/providers/osfstorage/60d58a5007e96e00e318b0f4?acti on $=$ download \&direct\&version=1\#page $=96$.

Nasution, S. H. (2018). Pentingnya Literasi Teknologi bagi Mahasiswa Calon Guru Matematika. Jurnal Kajian Pembelajaran Matematika, 2(1), 14-18. http://journal2.um.ac.id/index.php/jkpm/article/view/3168.

Nuriyawan, A., \& Wibawa, S. C. (2020). Studi Komparasi Penggunaan Platform Socrative dan Classdojo di Kelas Google Classroom. IT-Edu: Jurnal Information Technology and Education, 05(01), 262-272. https://ejournal.unesa.ac.id/index.php/it-edu/article/view/37484.

Pratama, H., Maduretno, T. W., \& Yusro, A. C. (2021). Online Learning Solution: Ice Breaking Application to Increase Student Motivation. Journal of Educational Science and Technology (EST), 7(1), 117-125. https://doi.org/10.26858/est.v7i1.19289.

Purnanto, A. W., \& Mahardika, A. (2017). Pelatihan Pembuatan Soal Interaktif dengan Program Wondershare Quiz Creator bagi Guru Sekolah Dasar di Kota Magelang. Warta LPM, 19(2), 141148. https://doi.org/10.23917/warta.v19i2.2748.

Raimanu, G. (2020). Mahasiswa terhadap Implementasi Pembelajaran Daring pada Masa Pandemi Covid19 (Studi pada Mahasiswa Fakultas Ekonomi Universitas Sintuwu Maroso). Ekomen, 19(2), 1-9. http://ojs.unsimar.ac.id/index.php/EkoMen/article/view/336.

Rigianti, H. A. (2020). Kendala Pembelajaran Daring Guru Sekolah Dasar di Kabupaten Banjarnegara. Jurnal Elementary School, 7(2), 297-302. https://doi.org/10.31316/esjurnal.v7i2.768.

Sa, S., Mei, A., Mei, M. F., Sero, M. T., Seto, S. B., Naja, F. Y., Denny, K., Meke, P., \& Manda, G. S. (2021). Bimbingan Belajar di Rumah Menggunakan Alat Peraga Blok Pecahan pada Masa Pandemi Covid19. Jurnal Pengabdian Masyarakat, 2(2), 193-201. https://doi.org/10.37478/mahajana.v2i2.1031.

Seraj, M., \& Wong, C. Y. (2014). Impacts of Different Mobile User Interfaces on Students' Satisfaction for Learning Dijkstra's Shortest Path Algorithm. International Journal of Interactive Mobile Technologies, 8(4), 24 - 30. https://doi.org/10.3991/ijim.v8i4.3860.

Sujiantari, N. K. (2016). Pengaruh Reward dan Punishment terhadap Motivasi Belajar Siswa dalam Pembelajaran IPS (Studi pada SMP Negeri 1 Singaraja kelas VIII Tahun Ajaran 2015/2016). Jurnal Jurusan Pendidikan Ekonomi (JJPE), 7(2), 1-10. https://doi.org/10.23887/jjpe.v7i2.7573.

Tindowen, D. J. C., Bassig, J. M., \& Cagurangan, J. A. (2017). Twenty-First-Century Skills of Alternative Learning System Learners. SAGE Open, 7(3), 1-8. https://doi.org/10.1177/2158244017726116.

Tohara, A. J. T., Shuhidan, S. M., Bahry, F. D. S., \& Nordin, M. N. bin. (2021). Exploring Digital Literacy 
Strategies for Students with Special Educational Needs in the Digital Age. Turkish Journal of Computer and Mathematics Education (TURCOMAT), 12(9), 3345-3358. https: //doi.org/10.17762/turcomat.v12i9.5741.

Vallely, K., \& Gibson, P. (2018). Engaging Students on Their Devices with Mentimeter. Compass: Journal of Learning and Teaching, 11(2), 1-6.

van Laar, E., van Deursen, A. J. A. M., van Dijk, J. A. G. M., \& de Haan, J. (2017). The Relation Between 21stCentury Skills and Digital Skills: A Systematic Literature Review. Computers in Human Behavior, 72, 577-588. https://doi.org/10.1016/j.chb.2017.03.010.

Virgiawan, M. D., Meryansumayeka, \& Marlini, S. (2018). Pengembangan Kuis Interaktif Berbasis ELearning dengan Menggunakan Aplikasi Wondershare Quiz Creator pada Mata Kuliah Belajar dan Pembelajaran Matematika. Jurnal Pendidikan Matematika, 12(1), 29-42. https: //doi.org/10.22342/jpm.12.1.5094.29-42.

Wang, T.-H., Lin, H.-C. K., Chen, H.-R., Huang, Y.-M., Yeh, W.-T., \& Li, C.-T. (2021). Usability of an Affective Emotional Learning Tutoring System for Mobile Devices. Sustainability (Switzerland), 13, 7890. https://doi.org/10.3390/su13147890. 